\title{
The Peaceful Road To Europe: Migration and the Setting of the Regular Long-Distance Coach Lines in the South-Western European Corridor (1960-1990)
}

\section{O Caminho Pacífico para a Europa: Migração e Criação de Carreiras Regulares de Longo Curso no Corredor do Sudoeste Europeu (1960-1990)}

\author{
Paulo Guimarães, \\ University of Évora, Portugal
}

\begin{abstract}
Resumo-A criação de carreiras regulares de longo curso em toda a Europa, impulsionada pelos fluxos migratórios, é o objeto deste estudo histórico centrado na experiência portuguesa. $O$ artigo considera quatro dimensões analíticas: o estabelecimento de carreiras regulares internacionais de longo curso por meio da coordenação dos modos de transporte; o enquadramento jurídico e a administração multinacional; a experiência de viagem de autocarro do migrante e, finalmente, as tendências evolutivas deste serviço. A narrativa baseou-se principalmente nos arquivos portugueses da administração dos transportes e na literatura técnica especializada. De contextos rurais a urbanos, de sociedades avançadas a menos avançadas na Europa, descrevemos o processo de mudanças sociais comuns induzidas pela experiência europeia. Este estudo explora a construção da Europa como uma experiência coletiva, histórica e cotidiana e analisa as maneiras como as instituições comuns, a confiança pessoal e até mesmo a amizade entre governos, funcionários e indivíduos foram construídas antecipando o processo político formal de criação da Comunidade Europeia.
\end{abstract}

Palavras-Chave-Sociedades Europeias; Redes de Transporte de Longa Distância Europeias; Século 20; Portugal.

\begin{abstract}
The establishment of the regular long-distance coach lines across Europe, boosted by migration flows, is the object of this historical study focused on the Portuguese experience. The article considers four dimensions: the establishment of the regular long-distance international coach lines through the coordination of the transport modes; the legal setting and the multi-national administration; the migrants coach travel experience and, finally, the evolutionary trends of this service. The narrative was mostly based on the Portuguese transport administration archives and specialized technical literature. From rural to urban contexts, from advanced to less advanced societies in Europe, we describe the process of common societal changes induced by the European experience. This explores the construction of Europe as a collective, historical and everyday experience, and analyses the ways common institutions, personal trust, and even friendship across governments, officials, and individuals were built anticipating the formal political process of creation of the European Community.
\end{abstract}

Keywords-European Societies; European Long Distance Transport Networks; 20th Century; Portugal.

Submitted-11-12-2020. Accepted-06-04-2021. 


\section{Introduction}

$\mathrm{F}$ Rom the late 1950s until the 1980s, the transnational labor movements from the Mediterranean basin and Turkey towards the Northwest European countries became the dominant European migration pattern (Moch 2003, 177-197; Bade 2002, 397-417; Tapia 1996). Countries like Portugal, Spain, Italy, Greece, and the former Yugoslavia, shifted the dominant transatlantic migration chain that existed since the 19th century to other Western European countries. Their economic importance grew as the migration flows decreased within the six European Economic Community (EEC) countries. Contemporary observers linked the increasing importance of those longdistance migration movements across Europe with the growing labor demand of industrialized countries during a period of fast economic growth on the one hand, and the demographic pressure of recruitment in the basins, on the other (Salt and Clout 1976, 2-29; 126-167). The associated flow of mass tourism and car use, combined with social mobility and policies, completes this picture of a new Western Europe during the so-called 'golden age' of capitalism.

In the late $1960 \mathrm{~s}$, during the summer season, migrant workers in France, Germany, or in the Benelux countries traveled through Europe on the same highways and roads used by tourists of those countries towards Portugal, Spain, Italy, Greece, and to the former Yugoslavia. They all followed the same seasonal course to the Mediterranean basin, often using the same car brands and national registrations. However, the travel experience of the migrants on the European roads and rails returning home to the Southern European periphery, or going to work in the more industrialized North, was very distinct from the one experienced by tourists. This collective experience on the road can be noticed, at least partially, through the regulative process of the longdistance coach services and its shared administration between several European governments since

- Paulo Guimarães, Assistant Professor at the University of Evvora and Integrated Member of the Research Center in Political Science (CICP).

E-mail: peg@uevora.pt

DOI:http://dx.doi.org/10.21814/perspectivas.3108 the late 1960s. Thus, in this article, we explore the existent international unity by analyzing the historical processes of peaceful integration in which transport was embedded and centered on services and infrastructures used for transnational mobility (cf. Schipper 2008). The historical case is the establishment of long-distance coach services in the South-western European corridor (PortugalSpain-France) associated with the increasing migration that connected the industrialized regions to the 'less advanced' periphery from the late 1950s to the 1990s. In this context, and having in mind the loose railroad network that was available and the low degree of urbanization, the coaches' flexibility became essential to provide a direct connection across European countries, between poor villages and small towns located in distant agrarian regions to the large European urban and industrialized centers.

The establishment of regular long-distance international coach lines ${ }^{1}$ was mainly an initiative of individuals and firms, although national governments strived to control and regulate those coach services to protect the interests of different types of national firms (railway companies, bus and coach companies, and travel agencies), to guarantee road safety and traffic control, or even to reinforce cross-bordering control. The coordination of the modes of transport became a transnational issue that compelled different governments to cooperate regularly. Thus, the second dimension of our analysis considers the legal setting and the multi-national administration of the long-distance coach lines in the Southwestern European corridor, issued in the mid-1970s. This was part of the integration process of the Southern administrative elites in the European arena, be-

1. The concept of regular long-distance international coach lines was defined by the Conference of European Ministers of Transport (ECMT) as the combination of a set of properties of the service provided: 'Long-distance' meant more than one hundred kilometres, not including cross border movements; 'International' because they often cross more than two countries; 'Regular' meant that prices and services provided by firms were known (publicized) and regulated, and the service were scheduled on a daily or weekly basis; 'Coach lines' were routes, stops and their service regime, defined in advance and regulated. This type of transport service must be provided to anyone at the stops previously defined in the terminal points and along the lines. These lines were established between the national transport administrations. On this regard see CEMT 1966, 1979. 
fore the democratic transition of the 1970s. The nationalist elites of the European periphery became interested and were present in international organizations, since, at that time, those countries had right-wing authoritarian regimes and ideals. In this perspective, the spurt of the new migratory stream opened a cycle of informal integration, induced cultural permeability, social convergence, and change in the advent of the political cycle in Southern Europe, marked by the transition to democracy.

The third dimension of this analysis explores the migrants coach travel experience in their close relationship with the services provided by the companies in business. Prices, schedules, stop locations, and luggage facilities display the strength of the service provided to transnational workers.

Finally, we consider the evolutionary trends of this transport service from the users' perspective. The difficulties created by governments to immigration since the 1970 s were followed by increasing demand for this type of service, due to the importance of the seasonal works in agriculture, tourism, construction, and other services, and the importance of family and kinship networks firmly established. The geographic growth of the labor and educational markets became an essential component of the demand for this service, which strives to grow alongside the expanding car and airplane competitors and the illegal services provided by private minibuses or vans.

\section{The setting of the regular long- distance coach lines in the South- Western European corridor (from the 1960 s to the 1970s)}

In the beginning of 1952, the High Council for Land Transportation examined the international transportation services by road in Portugal $^{2}$ for

2. Conselho Superior dos Transportes Terrestres (CSTT). The Council was created in 1946 in order to be the advisory board for the coordination of the railway and road transportation of the Ministry of Transport and Communications. It had representatives of all interested parties involved or affected by the current administrative decisions, mostly concerning concessions of bus and railways lines. The CSTT replaced the High Council of Traffic (Conselho Superior de Viação), created in 1928, with the additional competence of awarding bus and coach lines concessions, mainly considering the established interests of the railways. the first time. After reading the report from the committee nominated to study this issue, one of the counselors, an engineer, asked if a passenger could travel by coach from Hendaya, the FrenchSpanish border, to Lisbon. For the representatives of the bus and coach firms Association (GITA), the Portuguese railway company $(\mathrm{CP})$, the ports and roads administrations, the industry, the army, and the government, it came as an absolute surprise to be informed, at that moment, about the existence of a touristic organization called EuropaBus that explored 18,700 km of international lines (Portugal 1952). For them, the main concern became the new European scenario, particularly the possibility that concessions for international bus lines could jeopardize the so-called 'organization of transports' in Portugal, built in the 1930s from a nationalist stance. Until then, the transport of passengers and goods by road could only be done by vehicles registered in the country and belonging to Portuguese firms, and foreign vehicles needed special authorization, which was dilatory and usually also required an expensive bail (Braga 1969).

Despite having similar authoritarian regimes, the economic relations with Spain were dominated by contraband, and Spain was an obstacle to the connection with 'Europe'. The transportation of goods by trucks, organized in the 1940s between Portugal, France, Northern Italy, and Switzerland, soon ended due to difficulties raised by Spain, with the deterioration of the road infrastructures being one of the arguments. Almost all foreign trade from Portugal was done by sea, and, following the II World War, the emigration flux was revived, taking place across the Atlantic by ship (mainly to Brazil) ${ }^{3}$. Incoming tourists usually arrived at the port of Lisbon and used the routes that a few bus firms started to provide in the 1950s, exploring Portuguese historical sites, and soon after they began offering circuits to Spain. However, the growing number of incoming tourist coaches in the 1950s became more important, since it was considered an important source of foreign currency. The council worried that the difficulties felt in Portugal regarding the incoming

3. In 1967 , according to official statistics, 95.7 per cent of all imported goods (in weight) arrived to the country by sea, 4.2 per cent by land, and the remaining ( 0.1 per cent) by air. 
road traffic could trigger similar responses from other countries. This concern led the government to tune their policy by the principle of reciprocity and to participate in international forums to protect the nebula of land transport interests.

The Cabinet of Land Transportation Studies and Planning ${ }^{4}$, created in December of 1960 the same year the Stockholm Convention ${ }^{5}$ was signed - had a decisive role in the formation and internationalization of the technocratic elite that settled the Portuguese institutional arrangement for the participation in the transnational coach regular services. From 1961 to 1972, the Chief of the Cabinet actively participated in the European Conference of Ministers of Transport (ECMT) through the Committee of Deputies, being their president for ten years during a period where the organization was deeply committed to establishing a general transport policy for Europe (Portugal 1967; Lobato 2005) ${ }^{6}$. Their personnel received complementary knowledge in that context, attending specialized courses, post-graduate training, visiting international transport organizations and participating in several ECMT working groups. They considered transportation as a "function of the acceleration of the integration processes", and regarded this "pioneering experience"as "strategic for effective cooperation with practical results"(Portugal 1969). Benefiting from advanced technology and knowledge of transport management, they knew that the leading managers training and "harmonization policies"should lead to the "renewal of the mentalities of the leading elite".

On the other hand, given that the ECMT had defined earlier that their regulatory framework should be synchronized with EEC transport policy, the participation in that forum provided the opportunity to follow the European agenda. New information, conceptual models, and working procedures were adopted to redefine the internal transport policy during a period of steady economic growth and social modernization. The

4. Gabinete de Estudos e Planeamento dos Transportes Terrestres (GEPT).

5. Portugal was a founding member of the European Free Trade Association (EFTA).

6. The GEPT was extinct in 1972 and its personnel was integrated in the Direcção Geral dos Transportes Terrestres (Ministry of Transports and Communications) promotion of business concentration through the formation of regional bus transport companies was a concept that originated from the ECMT. It led to the government's strategy to organize regular services in the national interurban transport and the international bus transport business as well. However, it took more than a decade for the Portuguese administration to organize and establish regular services for migrants going to 'Europe' by coach.

There were three main reasons for this delay. In the first place, Portugal was the last Western European country in the Mediterranean basin of migrant recruitment to make the 'turn to Europe', i.e., to shift from the transatlantic flux that dominated until the II World War (Babiano and Farré 2002; Pérez and Barrientos 2005). Until 1954, the emigration to 'Europe' represented less than 2 percent of the total emigration and, by the end of that decade, it was 14 percent, representing less than 40,000 people leaving the country each year (Baganha 2003). At the time, there were already half a million Spaniard migrants, mostly in France, but from 1964 to 1969, legal emigration from Portugal rose to more than 50,000 departures per year, and 70 percent of that flux went to 'Europe', with France as the main destination (Graph 1). Thus, in the middle of the 1960s, there were already international coach services settled between France and Spain, providing regular services and specialized 'guest-workers' lines (also called ethnic) to working people, organized by bilateral agreements.

Graph 1: The Portuguese turn to Europe: emigration flows from Portugal to Brazil and Western Europe, 1950-1980

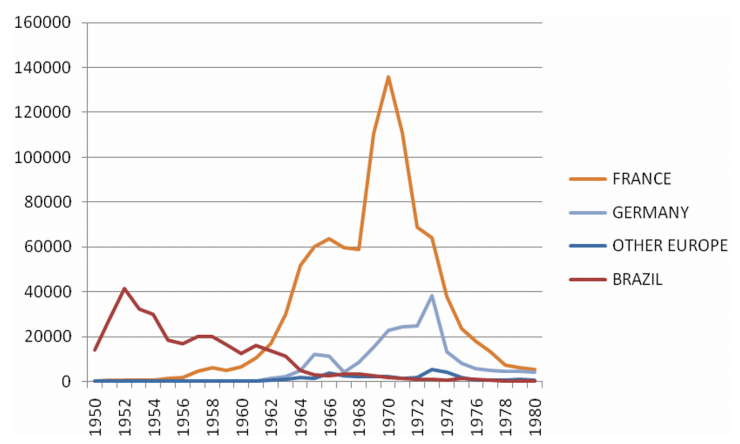

Data source: Baganha 2003. 
The second reason was the restrictive, discretionary and ambivalent policy of the Salazar government regarding emigration (Pereira 2009; Villanova 2006/7). There were reasons for the government to pursue a restrictive policy on emigration, namely the intensification of the war in the three Portuguese African colonies, the social and economic disruptive effect on rural communities (where the vast majority of the population lived), the agrarian interests and the industrial boost of manufactured goods, the last two dependent on cheap labor. But this restrictive policy did not limit the flux of the so-called 'rural overpopulation'. Despite bilateral agreements on workforce supply with France, Germany, and the Benelux, illegal emigration continued, and is estimated to be around 38 percent of the total. From 1961 to 1973, 841,000 Portuguese people went to France, 170,000 to Germany, and 26,000 to other European countries. In 1970, the country had 8.6 million inhabitants, 300,000 less than a decade before.

The continuation of this migration flux was not possible without the cooperation of the Spanish and French authorities. In the early 1960s, the political police (PIDE) and Guarda Nacional Republicana (GNR) persecuted (and sometimes assassinated) poor people who tried to illegally cross the Portuguese border to Spain, with the collaboration of the Spanish Guardia Civil. The Spanish police also detained and deported back people trying to reach the Pyrenees, sometimes on foot or hidden in trucks ${ }^{7}$. Taxis often transported 'illegal' migrants near crossing points and the smuggling networks sneaked them into Spain.

French authorities began to provide residence permits to everyone with employment contracts, so immigrants in France legally left their country with work contracts (which was one of the requirements to get a passport) and often had transportation paid in advance by the covenant. In this context, coaches and travel agencies issued collective bus tickets.

The third reason for the Portuguese delay in integrating the EMTC policies was the defensive

7. The French movie O Salto (1968), directed by Christian de Chalonge, documented this.

approach regarding the activity of foreign enterprises, which were eager to capture this passenger traffic. In 1962, new legislation restricted the entrance of unladen coaches registered outside Portugal to transport people to their country of origin $^{8}$. However, after 1965, the Junta Nacional de Emigração began to facilitate the reunification of family members living abroad. The initiative to organize regular services from Portugal to France emerged in that context. From 1964 to 1966, the Portuguese Transport Administration ${ }^{9}$ received nineteen applications from twelve national interurban bus enterprises to exploit regular lines going from several towns all over the Portuguese territory to the Spanish borders (table 1). In the list of applicants, we found both small companies and large regional bus operators with established international touring experience, such as Claras Transportes SARL. They both used the same administrative procedure for the concession of interurban lines. Nevertheless, the authorities made no definitive decision for several years, arguing the absence of internal legislation on international bus and coach transport services. In practice, the authorities did not take notice of those 'illegal' services.

Table 1: Interurban coach firms and applications for the concessions of regular lines to the Spanish-Portuguese borders, 1964-1970.

\begin{tabular}{|c|c|c|}
\hline Year & Bus Firms (no.) & Applications (no.) \\
\hline 1964 & 1 & 1 \\
\hline 1965 & 4 & 6 \\
\hline 1966 & 9 & 12 \\
\hline 1970 & 2 & 2 \\
\hline Total & 14 & 21 \\
\hline
\end{tabular}

Note: some bus firms appeared in several years with different applications.

Source: IMTT archive - Applications for bus lines concessions.

8. Decree number 44,781, of December 7th, 1962. See also Braga 1969.

9. Direcção-Geral de Viação 


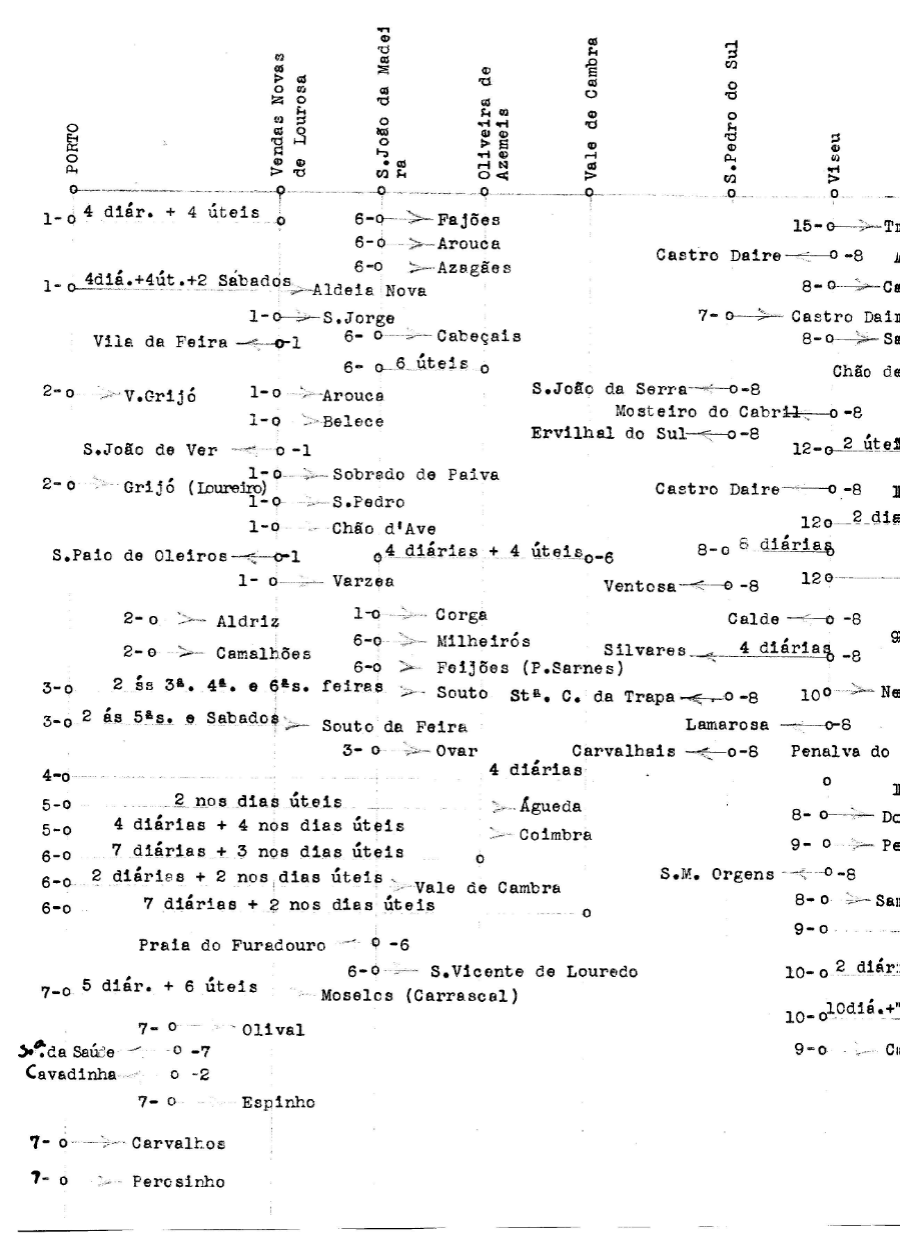

Figure 1: Study plan (extract) to create scheduled connections between the local and regional bus and coach lines in Portugal and the international coach lines from Porto to France (detail of the plan for Aveiro District), 1979 IMTT archive (International lines).

Similar initiatives took place in France at the time. In August of 1965, the SEAFEP (Société d'Exploitation d'Autocars France, Espagne, Portugal) was created in Paris by three Parisian transport enterprises and other nine from the Basque country. With Jean-Louis Larronde as its first director, the Société began to operate in 1958 by making occasional services, loading and unloading passengers on return, which was illegal (Mavropolos and Louis-Larronde 2008). The French government intervened, assigning jurisdiction of the international bus lines authorizations to SEAFEP, SCETA (the road branch of the French railways' company SNCF), and SGTD (Société Générale des Transports Départementaux). Agreements between the French and Spanish adminis- trations were settled, followed by authorizations to create regular international road lines. This way, the market was portioned between transport enterprises of both countries, in a way that railway interests were also protected. In practice, the emigrants that legally left Portugal using 'illegal' coach services provided by a local or regional company, could find buses connecting with international lines at the Spanish-Portuguese borders. On the other hand, migrants did return every year to spend the holidays in their rural communities or villages, leaving no choice to the authorities but to look the other way, ignoring the giant seasonal traffic. Most of the transportation services were provided by coaches as occasional services promoted by travel agencies, in close relations with interurban coach enterprises.

Nevertheless, in the 1960s, the railway attracted the majority of the emigrants' transport demand, but, in many cases, its use was unpractical for rural populations. This trend was not favorable for $\mathrm{CP}$, the Portuguese railway company. Coaches were well infiltrated in rural areas, linking remote and less advanced places directly to the industrialized European regions and larger European cities.

At the highest institutional level, a general political consensus emerged regarding the need for 'liberation' of the established national regimes, concerning certain types of international road transport, in the form of the Resolution 16 of the ECMT in 1965 (Paris, November 26th). This Resolution advised the national European governments to abolish the system of quotas and authorizations for occasional road transport of people who traveled in 'closed-door' circuits. This had a direct impact on coach tourism business activities and migrant's road transportation as well, beyond the EEC original borders. ${ }^{10}$ Despite this, most issues related to the different national interests and rules on the access to markets, tax policies, competition, technical and safety requirements,

10. Moreover, a general conceptual framework was established and became the basis for future negotiations. The concept of "international road transport of passengers"was defined as a route with more than 100 kilometres between the points of departure and arrival, being also distinct of the trans-border transport and of the conveying transport. The 17th ECTM Council Meeting established a synchronism between the EEC and the ECMT, concerning the legal and technical basis of transport policy. 
and social regulations were settled through bilateral agreements, and not as much by multilateral or general treaties.

\section{The contested creation of the In- ters' pools in Portugal}

The principles for the organization of international road passenger services by the Portuguese government were only defined in 1971, with the explicit goal to take advantage of the migrants' need for transportation. Having in mind the country's growing efforts for European economic integration, the government recognized that the absence of a legal framework for on-road transportation was an institutional obstacle to the participation of the Portuguese transport enterprises in that market. ${ }^{11}$ The explicit objective was protectionism and, regarding passenger transportation, the traffic administration wanted to place the international services in the hands of regional bus companies. However, those companies still had to be created. The government conducted the business organization of the international coach regular services by establishing agreements with Spain, France, and Holland. But the pressure came from outside. In what concerned the transportation services done by foreign companies, the regulation followed the ECMT recommendations, and the rules were generally applied in the Western European countries. The Portuguese territory was divided into three geographic areas for the exploration of the passengers' market, grouping several districts in the North, Centre, and South. ${ }^{12}$ Only interurban coach firms could join the regional pool for the exploration of international lines, and these were, in its majority, very small and familybased. They had been exploring the interurban lines that deeply penetrated rural areas for many decades, building a close relationship with the population. Altogether, they formed a tight network

11. See Decree-Law no. $477 / 71$, of November 6 th. For regulation see Decree no. 45/72, of February 5th (Diário do Governo I série, 30, pp.136-150)

12. The North grouped the districts of Viana do Castelo, Braga, Vila Real, Bragança, Porto, Aveiro, Viseu e Guarda. The Centre embraced the districts of Coimbra, Leiria, Castelo Branco, Lisboa e Santarém. The South included Portalegre, Évora, Setúbal, Beja e Faro. See Decree no. 45/72, of February 5th. linking very small (and otherwise isolated villages) to sub-regional small towns. In other words, they were able to create an infrastructure that directly linked remote rural areas to the largest European industrial centers and cities.

The new regional companies, called Internorte, Intercentro, and Intersul, were accordingly attributed a share of the regional market, estimated by the quota of the total regular interurban concessions owned by each company. The interests of the railway company $\mathrm{CP}$ were dually protected, first by joining the pools, and second by a tax policy that over-charged road lines that were considered competitors of the railway lines. The government policy also intended to be the first step to create regional bus companies soon, but the decision had to come from the owners of bus companies. At the same time, the creation of the Inters was the solution found by the administration for the deep contention between the two groups of companies already established in the field. Sonero was the oldest group of interurban companies determined to obtain the monopoly of the international bus lines concessions in Portugal. They represented the interests of 75 firms, including CP. The other group was TRIL - Transportes Internacionais Rodoviários, Lda., which integrated 26 firms in the region between the rivers Douro and Tagus. In the words of one high civil servant of the Traffic Administration, "both firms had benefitted from an attitude of tolerance by the public authorities - which implicitly recognized the need for those transportations, as long as the regulation of those services was not published - to assure, using their associates' vehicles, the transport of thousands of passengers that were brought to our borders by French and Spanish transporters". ${ }^{13}$

The opportunity for Sonero to contest the Inters' organization came two months after the unexpected Carnation Revolution in 1974, when the new State Secretary of Transport signed an order granting three authorizations for the direct exploration of services between Portugal and France based on mutual reciprocity. Sonero demanded "the immediate suspension of the activity of regional firms created by legislation of the fascist re-

13. IMTT Archive, 123/74/DST/TI, fl.5 (our translation). 
gime". ${ }^{14}$ Three years before, the group had defined itself as a "national concentration"of firms "created from the useful corporative legislation". But now their agents distributed pamphlets to the population claiming to be a "cooperative"struggling against "fascist monopolies". However, the intentions to eliminate the Inters or the international concessions was refused by the new revolutionary government because the "law of the dethroned regime should be considered revoked only if it was against the principles of the Program of the Movement of the Armed Forces (MFA) or against other international agreements that Portugal had, meanwhile, signed and contradicted the former law". ${ }^{15}$

The new government maintained its leading role on this issue, so the current management of the international regular lines was coordinated between the national administrations of the counties interested in that traffic, on the one hand, and the companies, on the other. The continuation of the operation of 'illegal' international regular services by bus companies was the acknowledgement that the government could not supervise the conditions in which the services were provided, namely, tariffs, itineraries, vehicles security, timetables, and passenger comfort. By maintaining this situation, the government faced the risk of international discredit, since the creation of the lines to France was an issue delayed for many years, despite the constant insistence and pressure coming from other administrations. Until then, passengers who traveled abroad using regular coach services were transported in the same vehicles used by the companies in regular lines, being loaded and unloaded at the Portuguese borders. Migrants going to France had to change transport twice during the travel, first to a Spanish coach, and then to a French one. The journey had to follow existing coach routes created to serve the Spanish-French users. Thus, the government's goal was to create 'direct services' in such a way that the Portuguese part could have a larger share in the profits of traffic generated by nationals.

14. IMTT Archive, 120/74/DST/TI, fl.9

15. IMTT Archive, 120/74/DST/TI, fl.7

\section{The Migrant's European collective experience on the road}

In November of 1975, during the negotiations of the Portuguese-French-Spanish protocol for the exploration of the international coach services, it became clear that "the connection of several affluent bus lines was vital due to the great dissemination of the origin and destination points of the passengers (almost all migrants)". ${ }^{16}$ Those lines should also be explored by the pool, and for that reason, it was necessary to establish an agreement with the French and Spanish administrations. The branch lines in Portugal and France decreased the number of transshipments, and solved the problem of lack of time coordination between regional and international lines.

To fully understand the importance of this issue, we must be aware of the way migrants, coming from rural and poor communities, experienced those travels across the Southwest European corridor. For them, luggage was the most important issue: they carried not only a suitcase limited to twenty kilos and a hand-bag, as it was officially established, but also bottles of wine, carboys of home-made brandy and olive oil, and food. In sum, an array of goods that could include, in the limit, boxes with nails to make a wooden tent in Champigny-sur-Marne (the biggest European slum, occupied by Portuguese and Maghreb people). ${ }^{17}$ The sympathetic attitude of the drivers, their intermediation role when dealing with customs authorities, or knowing where to exchange money at favorable rates, were valuable services that we hardly find mentioned in state archives. But one can understand how long coach travels could easily become a nightmare: "We were treated as if we were Indians (meaning Noncivilized)", wrote a migrant living in France. "The Spanish drivers did not allow us to take our bags with food and they only made a stop when they wanted to. They didn't stop for our 'physiological needs' and the ladies were forced to do their 'needs' in plastic bags in the coach. They even

16. Official letter of the board of directors of the three Inters to DGTT, Lisbon, November 4th, 1975 (IMTT Archive).

17. In 1979, the ECMT recognized the difficulties the railway transports felt dealing with, heavy luggage, saying "le transport des bagages est souvent un inconvenient dissuasif qui n'a jamais été techniquement résolut"(ECMT 1979, 53). 
physically threatened the passengers (...) With the French [drivers], we were a real family". ${ }^{18}$

Migrants wanted to stay as much time as they could in their hometown and, for that reason, travels had limited stops along the way. Taking the risk of presenting a common stereotype, one could say that migrants worked and made 'sacrifices' all year abroad to enjoy a few summer days in their home villages, where rural communities were symbolically rebuilt in annual feasts. Thus, the reasoning behind their choice of transport mode does not consider only price, an important and often crucial variable indeed, but also the time that took to go from their workplace (meaning the place abroad where they live for eleven months) to their community and other facilities. In this regard, coach travels were similar to the migrants use of the car during the same travels, and the price paid for that was often high.

The flexibility of the coach, when compared with railways, became a key feature simply because it could load and unload people and their goods near the origin and the destination points. The stops in the line of Lyon, in France, included not only bus stations in towns but also squares, areas in front of factories, or the headquarters of coach firms. The loading and unloading places throughout the line of Paris also mentioned similar places in towns and others, such as "at the statue", or "before the bridge that crosses the river", or "in front of the municipal hall", with the departure or the end of the line at Pont de Charenton (Paris). For each international line, the timetables and the schedules of regular bus services and fares were printed as an origin-destination table, in a similar way to the national interurban lines, since buses loaded people along the line in the country of origin and unloaded them along the journey. In Spain, coaches traveled in 'closed-door'. Moreover, the origin-destination points were not only between Lisbon, Porto, and Lyon or Cologne, but also (and mainly) between places like Sabugal, a tiny town in the Centre of Portugal, and Massy, near Paris, or Lagos (Algarve) and Hannover (see table 2, figure 1).

18. Handwritten letter dated March 7th, 1977 (IMTT archive, International Lines Proceedings, Spain).
Table 2: Villages and towns served in Portugal by some international bus regular lines from/to France (sample), 1976.

\begin{tabular}{|l|l|l|l|l|}
\hline $\begin{array}{l}\text { Incoming / } \\
\text { outgoing } \\
\text { route }\end{array}$ & $\begin{array}{l}\text { Days } \\
\text { per } \\
\text { week }\end{array}$ & $\begin{array}{l}\text { Time } \\
\text { to the } \\
\text { border }\end{array}$ & $\begin{array}{l}\text { Main villages and towns served (load } \\
\text { /unload stops) }\end{array}$ & Border \\
\hline $\begin{array}{l}\text { Almada } \\
\text { (Lisbon) }\end{array}$ & 2 & $4: 30$ & $\begin{array}{l}\text { Almada - Montijo - Setúbal - } \\
\text { Montemor-o-Novo - Estremoz }\end{array}$ & Caia \\
\hline $\begin{array}{l}\text { Castelo } \\
\text { Branco }\end{array}$ & 7 & $4: 30$ & $\begin{array}{l}\text { Castelo Branco - Lardosa - Alpedrinha } \\
\text {-Fundão - Covilhã - Canhoso - Caria } \\
\text { - Terreiro das Bruxas }\end{array}$ & $\begin{array}{l}\text { Vilar } \\
\text { Formoso }\end{array}$ \\
\hline Aveiro & 2 & $\begin{array}{l}7: 30 \\
\left(^{*}\right)\end{array}$ & $\begin{array}{l}\text { Aveiro - Ílhavo - Vagos - Anadia - } \\
\text { Mealhada - Mortágua - Sta. Comba } \\
\text { Dão - Carregal do Sal - Oliveirinha - } \\
\text { Nelas - Mangualde - Fornos de } \\
\text { Algodres - Celorico da Beira - Guarda } \\
\text { - Pínzio }\end{array}$ & $\begin{array}{l}\text { Vilar } \\
\text { Formoso }\end{array}$ \\
\hline Porto & 5 & $\begin{array}{l}9: 30 \\
(*)\end{array}$ & $\begin{array}{l}\text { Porto - V.N. Lourosa - S.J. Madeira - } \\
\text { Oliveira de Azeméis - Vale de Cambra } \\
\text {-S. Pedro do Sul - Viseu - Mangualde } \\
- \text { Fornos de Algodres - Celorico da } \\
\text { Beira - Guarda - Plínzio - }\end{array}$ & $\begin{array}{l}\text { Vilar } \\
\text { Formoso }\end{array}$ \\
\hline
\end{tabular}

Source: IMTT archive International road passenger lines. *1 hour stop

Table 3: European cities, towns and villages served by international regular bus lines from/to

France (lines of Lyon, Toulouse, Paris and Germany) exploited by Intercars-Paris, 1976.

\begin{tabular}{|l|l|l|l|l|}
\hline Bus line & $\begin{array}{l}\text { Days } \\
\text { per } \\
\text { week }\end{array}$ & $\begin{array}{l}\text { Time } \\
\text { to the } \\
\text { border }\end{array}$ & $\begin{array}{l}\text { Main cities, towns and villages served } \\
\text { (lade /unlade stops) }\end{array}$ & $\begin{array}{l}\text { French } \\
\text { Spanish } \\
\text { Border }\end{array}$ \\
\hline Lyon & 6 & $9: 30$ & $\begin{array}{l}\text { S. Vicente Tirosse - Castets - Bordeaux } \\
\text { - Perigeux - Brive - Tulle - Egletons - } \\
\text { Ussel - Clerm Ferrand - S. Etienne - } \\
\text { Rive de Gier - Givors - Vienne - Lyon }\end{array}$ & $\begin{array}{l}\text { Behobi - } \\
\text { Bayone }\end{array}$ \\
\hline Toulouse & 7 & $5: 45$ & $\begin{array}{l}\text { Orthiez - Pau - Tarbes - Lannemezan, } \\
\text { ST. Gaudens - Toulouse }\end{array}$ & $\begin{array}{l}\text { Behobi - } \\
\text { Bayone }\end{array}$ \\
\hline $\begin{array}{l}\text { Paris } \\
\text { (National } \\
\text { 20) }\end{array}$ & 7 & $10: 00$ & $\begin{array}{l}\text { Castets - Bordeaux - Angoleme - } \\
\text { Poitiers - Montbazon - Tours - Blois - } \\
\text { Men - Beaugenes - Orleans - Ltampes } \\
- \text { Arpajon - Montlhery - Cransi - } \\
\text { Massy - Paris }\end{array}$ & $\begin{array}{l}\text { Behobi - } \\
\text { Bayone }\end{array}$ \\
\hline $\begin{array}{l}\text { Belgium } \\
\text { and } \\
\text { Germany } \\
(*)\end{array}$ & 2 & $9: 30$ & $\begin{array}{l}\text { Bordeaux - Tours - Paris - } \\
\text { Valenciennes } \\
\text { - Bruxelles - Liege - Cologne, branche } \\
\text { to : } \\
- \text { Dusseldorf } \\
- \text { Osnabruck } \\
\text { - Bremen - Hamburg }\end{array}$ & Irun/Hendaye \\
\hline
\end{tabular}

Source: IMTT archive International road passenger lines. *line branches from Paris 
Figure 2: Portuguese Migrants at the Porte de Charenton (Paris) departing to Portugal in December 1982. For migrants, luggage was an important issue.

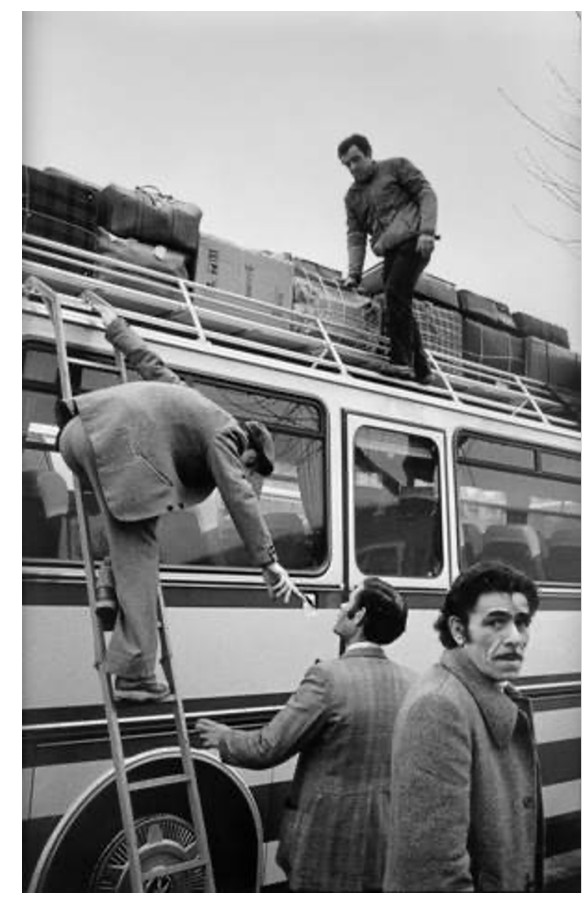

Photo: António Pedro Ferreira.

Graph 2: Fares by transport mode and distance (1987).

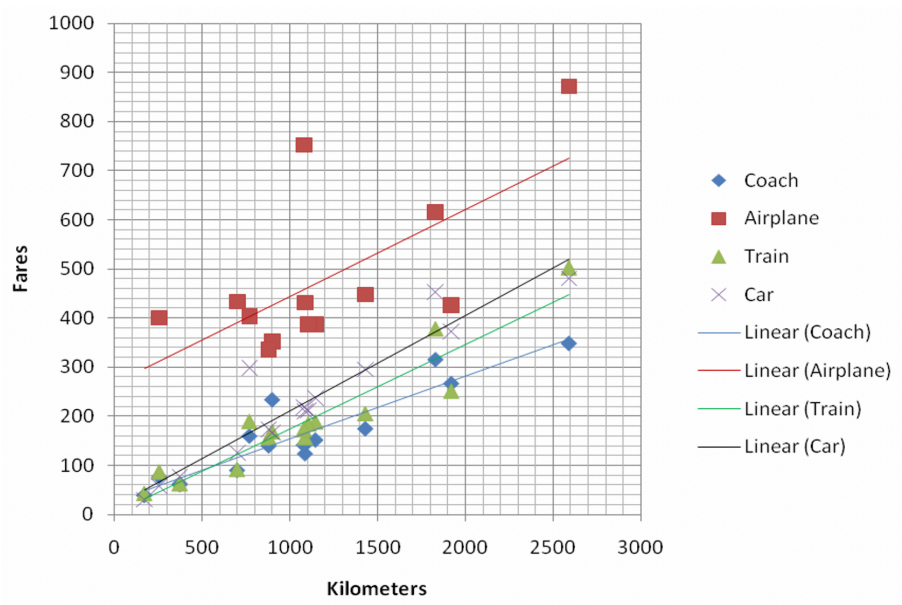

Data source: CEMT 1988, 25.

Note: Values in thousands of liras. The travel costs for cars were calculated for four passengers per travel.
The regular service provided that the passenger spent the minimum possible time traveling. These were not trips to enjoy or travels with tourist features on the way. The time assigned for lunch breaks or pauses for meals was often just one hour and the night was for traveling. People not only slept on board but also ate and drank, avoiding spending money in the restaurants chosen by the companies along the road. The timetable was also optimized considering the time of arrival to the Spanish and Portuguese borders, which were closed during the night, to spend just the necessary time to cross them. Moreover, every 'mandatory' pause during the route was considered a waste of time. For instance, as late as 1984, the 1,830 km journey from Paris to Lisbon took 31 hours to make (Portugal 1986). It would start at 10:00 a.m., with a one-hour lunch break, a twenty-minute 'technical break' in the afternoon and another hour break for dinner. The journey continued during the night. The next day, there was a thirty-minute break at the PortugueseSpanish border and another one-hour pause for lunch. The commercial speed was about $57 \mathrm{~km}$ per hour on average or $65 \mathrm{~km}$ per hour on the road. The bus travel from Paris to Faro (Algarve) took more than 31 hours, unequally divided between France (11h 15m), Spain (9h), and Portugal (12h). The line from Braga to Luxemburg took 40 hours and had 12 stops totaling 8 hours (Portugal 1987, $30)$.

The characteristics of the road and the absence of highway infrastructures in the Iberian Peninsula do not fully explain the long time spent traveling. Even in France, coach companies used the national roads instead of highways, partially for economic reasons. The other reason is that people were loaded and unloaded near their destination along the line. As a result of this management, the coach services were much cheaper than the alternative railway. ${ }^{19}$

The travel was harsh not only for passengers but also for drivers. Normally every bus carried two drivers that alternated driving on board. Hence, it was not surprising that the implemen-

19. According to the data in Italy during the late 1980s that compares travel costs by transportation types and distance. This was used by the Portuguese administration at the time (see Graph 2). 
tation of AETR created a problem for everyone in the business. When the French government notified the Portuguese authorities that they would take action against those that did not follow the AETR regulation, ${ }^{20}$ all the companies interested in lines to France joined forces against it, claiming that it was not feasible due to the traffic characteristics. The safety concerns were genuine, particularly in 'direct travels', because substitute drivers also slept in coaches during trips. The tachometer became compulsory and the 'technical breaks' were somehow met, but the double drivercrew on board continued.

Graph 3: Monthly distribution of the incoming and outgoing passengers in the coach lines to France and Germany, 1982.

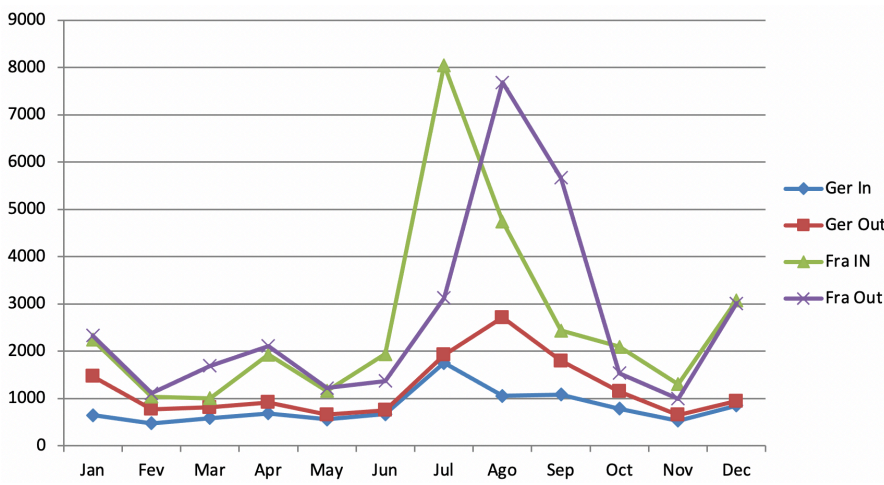

Sources: IMTT archive Portugal 1986, pp.27-28.

Another feature of this service was its highly seasonal demand. Most migrants returned to their country of origin during the summer for holidays, joining the increasing tourist flux to the Iberian Peninsula. In the end of September, the demand fell to lower levels until December, given that many migrants returned home for Christmas and the New Year. Finally, at Easter, the traffic increased again. For the international pool organized between governments, the concentration of the demand during these short periods required a large capacity to dispose of sufficient coaches in these few months during the year (graph 3). The

20. The AETR is the European Agreement Concerning the Work of Crews of Vehicles Engaged in International Road Transport. Although concluded in 1970, it was ratified by Portugal three years later, and their dispositions were only regulated in 1982. The AETR was built on the EEC 543/1969 regulation. easy solution found for this was to use another coach available from other services, either touristic or interurban. For this reason, the Portuguese administration resisted registering coaches for international services, linking that registration to the lines' concessions. In addition, there was also a considerable difference in the demand for travels in both directions in different months and days, thus forcing companies to make frequent unladen travels. The practical solution found for this problem was often to charge tariffs with extra-rate taxes during the 'high seasons'. During the low seasons, the coaches traveled in the Portuguese line branches of the international lines below their minimum optimal capacity. The travelers from different line branches were then placed together in single groups at the borders, and moved to Spanish coaches. The Portuguese regional lines' branches were in themselves unprofitable and, for that reason, the other State administrations of the pool, particularly the French, had to accept that doubled tree structure of the international lines in France and Portugal. Thus, regular lines from Portugal to Luxembourg, Switzerland, and Germany were created in the mid 1970s in France, in many cases being the extension of previous lines to that country.

\section{The joint administration of the in- ternational road passenger lines}

The international bus lines concessions were given to companies by all governments for a limited time (three years) and one specific international line. The authorizations also specified the conditions in which they had been granted. For instance, the change of ownership of a firm in one country should also be approved by the other administrations that had given the concession. In the case of the lines leaving or coming to Portugal from France or Germany, they went through Spain on 'closed doors'. ${ }^{21}$

The organization of the international pool demanded a significant effort of negotiation, coordination, and mutual supervision. These required regular information exchange and meetings

21. PORTUGAL, M.T.C.; G.E.P.: Informação complementar ao Relatório, p. 19. 
between the companies' representatives and governments of the countries involved in the business, where divergent interests and perspectives were present. All parties agreed that the exploration of the regular lines should be done by a pool. Each country had chosen a small number of companies for the business. In 1976, Portugal had three Inters, in Spain there was ATCAR, associated with the Spanish railway company called Renfe, in France there were the IntercarsParis, the Intercars-Lyon, and the France-Cars. ${ }^{22}$ For the exploration of each line, all issues had to be negotiated between companies and governments. The tariffs' income was divided between companies proportionally to the distance covered by the international line in each country. One can illustrate this through the agreement established in Madrid, on November 3th, 1976, for the exploration of the daily line Viana do CasteloParis between the representatives of Internorte, Intercars-Paris, and Renfe-ATCAR, the companies that had created it. Part of the value of tickets to France sold in Portugal, concerning the part of the line traveled in Spain and France, was sent to Renfe-ATCAR and Intercars-Paris by Internorte every week. In France, Intercars-Paris took the tickets for the travel in French territory and, in the opposite direction, they followed a similar scheme. The control of the tickets sold was carried out in the borders' relays of the three countries. In these meetings the tariffs, the price policy regarding currency depreciation, the exemption of the vehicles' registers, and mutual responsibilities were also established.

Cooperation coexisted with fierce competition between national-based firms to obtain the maximum share of the traffic income. Spanish companies also wanted to sell tickets in Portugal, but the Portuguese government only allowed that if Spain abolished the obligation of closed-doors travels in their territory. The Minister of Transports had exceptionally allowed stops in Zamora, Burgos, and Irún for that line. The freedom of commercialization in the three countries was discussed

22. The rights of ATCAR were given to the Spanish Sociedad Internacional de Autocars, SA created in July 30th, 1979, in Madrid by RENFE, CIBERTANSA, Companhia Ibero-Americana de Transportes, SA, T.A.C. Sociedad de Transportes Terrestres Combinados, SA and ALSA. with no results, but the principle of the unified exploitation of the line was assured through the information of the sales by the central booking of each country.

In the summer of 1978, there was a deterioration in the relations between companies. French companies had begun to apply additional rates due to the depreciation of the Portuguese currency and the raise of the operational costs. The new tariffs were communicated by the French government to the Portuguese administration by phone. Intercars-Paris and Intercars-Lyon had begun to sell their tickets in Portugal, refusing to negotiate any rules of commercialization. French and Spanish firms had begun to take decisions unilaterally and were the first to receive complaints about delays and lack of payments from the others. France-Cars had done "parallel"travels from the North of Portugal for several years, using the authorizations of Intercars-Paris, without providing any information to the other partners in the pool. Due to the rivalry and lack of agreement between Intercars-Paris and the France-Cars on the lines that 'belonged' to each one, the French authorizations for the lines Portugal-Paris ceased on May 1st, 1979. This issue was overcome in a meeting between those companies and G.T.I and S.C.E.T.A., and the information was sent to the Minister of Transports of the three countries. New authorizations followed.

The organization of the regular services in Portugal with the former Western German administration only took place in the early 1980s. The request for authorizations to 'new' lines was submitted to the Ministry of Transports and Communications in November of 1983, following the negotiations that had taken place in Bohn during the previous year. The initiative came from the Federal Railways through their Bus Department at Dusseldorf, the manager of Deutsche Touring GmbH of Frankfurt on the Main. In the request for authorizations, SCETA (Service Routier de Voyageurs, Levalloi-Perret), SAIA (Internacional de Autocares, S.A., Madrid), Les Autocares l'Epervier, S.A., Brussels and the three Portuguese Inters were also present. Basically, the pool wanted an extension to the line T92 Cologne-Madrid (by Irun/Behobia and BurgosFuente de Oñoro) to Viseu-Porto, Coimbra-Lisboa 
and Évora-Faro (by Vilar Formoso). At the time, this bus line had connections to Cologne from San Sebastian, Burgos, and Madrid, with departures from the Spanish capital to Cordova - Seville, Aranjuez, and Manzanares. The travel to Madrid took 29 hours (or 27 hours to Burgos), using three drivers and with six breaks (of 4 hours in total). Burgos received passengers coming from Viana do Castelo, Porto, Lisbon, Faro, and Lagos to Cologne. The travel from Lisbon took at least 40 hours.

The German administration wanted all ticket sales in their territory to be done by the Deutsche Touring GmbH, and only one bus stop in Germany, the international bus central station in Cologne. Concerns with control and safety were also central: only specific vehicles registered for that traffic would be allowed, and timetables could not be modified without prior authorization. On the other hand, the Portuguese administration intended the lines from Portugal not to become part of the previous bus lines network based in Spain. The regular lines from Portugal to Germany had to be established between the two countries and to be based on "their own needs". Each line service should require its authorization and the sanction on one service should not affect the rest of the concessions. Although Portugal was in a worse bargaining situation, the organization of the international lines would have to be done by consensus and that would only be feasible if an agreement between all administrations involved was reached.

However, the creation of regular services did not stop the 'illegal' international coach travels, very often promoted by travel agencies, who had been in this line of business from the start. In 1976, for instance, one travel agency settled in the small town of Viseu, in association with the other two from Lisbon and Porto, and sold bus tickets to Frankfurt. There were at least 17 travels, most of them in July and September. That company was also an important seller of Inters tickets. In France, at the same time, it was calculated that the travel agency "Lopez Voyages"sold 50 percent of all round-trip tickets from Paris to Portugal.

\section{Crisis and revitalization (from the 1980 s to 1990 s)}

Following the 1973-1974 crisis, the Portuguese emigration to France and Germany abruptly fell (see Graph 1). The 'open doors' policy pleads by the governments after the Carnation Revolution of April 1974, and the return of half a million Portuguese from the colonies did not reverse that trend, due to the harsh conditions the migrant workforce endured in the destination countries. After 1978, emigration became residual and the remittances fell to historically low levels, announcing the end of the "guest-workers"model (Castles 1986; Messina 2002; Triadafilopoulos and Schonwalder 2007). Internally, as a consequence of the revolution, the major companies in crucial economic sectors were nationalized. The struggle of bus drivers and transport workers within large and medium-size firms led to their nationalization. Most of the large firms in the center and south of the country were merged into Rodoviária Nacional (RN), created by the government during the revolutionary process. Therefore, the Inters were now controlled by the state-owned RN. ${ }^{23}$ The private sector was reduced to small bus firms that had few interurban lines, and some of them had special services (such as providing transportation to factories and schools), and others became associated with agencies to explore incoming tourism and, additionally, outgoing tourism. Also, increasing numbers of migrants preferred to travel by car with their relatives during the holidays. After the investment in housing (symbol of economic success and status in the community), the car followed in the list of priorities, allowing people to travel across Portugal as never before, visiting family and friends or just discovering the country and celebrating their cultural identity.

However, the international bus lines did not lose relevance and the activity of the Inters grew steadily in this new context. Since the end of the 1970s, Luxembourg and Switzerland became important destinations, although there was a simultaneous and increasing flux of returns from the mid 1980s (Marques 2009). There were also

23. In 1984, the State-owned enterprise Rodoviária Nacional $(\mathrm{RN})$ had 78 per cent of the shares of Intercentro, 80 per cent of Intersul and 15 per cent of Internorte (RN, 1985). 
more seasonal departures in the reverse way of the normal flux, that is, many people traveled to 'Europe' to work regularly during short periods, especially during the summertime, in places such as the vineyards in the South of France, or Switzerland's hotels and restaurants. Moreover, given the increasing difficulties raised to the entrance of migrants, many people traveled as tourists, often using previous network support, until they could find a regular job to be qualified to have a residence permit. ${ }^{24}$ Temporarily unemployed people returned to the South until better opportunities emerged abroad, and many of them also used the long-distance coach lines to visit relatives and friends living abroad. All these cross movements of people increased the demand for long-distance passenger road services. In 1982, more than 260 thousand people had used 67 registered regular coach lines from and to Portugal. ${ }^{25}$ With around 200 thousand users in the middle of the 1980s, in a time when many of the migrants who had left the country in the 1960s and 1970s were returning, the line to Paris was considered the most important long-distance regular passenger road line in Western Europe. In the year before Portugal joined the EEC, "the large majority of passengers transported (by coaches) were migrants and their families. The percentage of migrants should be between 80 and 90 percent"(Portugal 1987, 27). Although immigration had increased in the Mediterranean basin (Mendoza 2009; Messina, 2002), the stock of temporary and 'illegal' Portuguese migrants in Western Europe grew after the formal integration in the EEC in 1986, and increased steadily since the 1990s to Switzerland, United Kingdom, Germany, and Spain. In the new context, coach services reached then half-million users.

24. In $1982,75,8$ per cent of the low class Portuguese that left the country were temporary migrants, and the remaining declared to be tourists. The numbers for the so-called 'lower middle class' were on the 30,7 per cent, but 46,6 per cent stated they were visiting family abroad (Survey made by Lemos and Silva in 1984 for the Portuguese Transport Administration).

25. The line to Paris transported 165 thousand passengers, the line to Lyon 72 thousand, to Germany 19 thousand and the line to Madrid and Barcelona 6 thousand. It was estimated that 1,4 million migrants used individual vehicles. (Internal data from the Cabinet of Studies and Planning of Transport and Communication, now at custody of IMTT, Portugal. See Portugal 1987, p. 20).
Table 4: Regular long-distance coach lines from Portugal to European countries: weekly departures by areas of origin and destination (1982).

\begin{tabular}{|l|c|c|c|c|c|c|c|c|c|}
\hline Portugal & Paris & Lyon & Genève & Zurich & Koln & Luxembourg & Madrid & Barcelona & Orense \\
\hline North & 14 & 7 & 4 & 2 & 4 & 1 & - & - & 4 \\
\hline Centre & 6 & 4 & 2 & 2 & 2 & 1 & 2 & 1 & - \\
\hline South & 4 & 3 & 1 & 1 & 2 & 1 & - & - & - \\
\hline Total & 24 & 14 & 7 & 4 & 8 & 3 & 2 & 1 & 4 \\
\hline
\end{tabular}

Source: IMTT archive - Portugal, M.T.C.; G.E.P., Informação complementar..., p.18.

Although the setting of the international regular coach services by the administrations had been motivated by the 'old' issue of transport coordination, to assure the interests of the railway companies and the national firms, both modes of transportation had lost the competition to automobiles in the first place, and to airplane services, as the fares' prices started to fall also due to the organization of charter flights. The years 1983-1986 presented an expressive increase in the air traffic from Portugal, Spain, and Morocco. ${ }^{26}$ During this period, 53,5 million people crossed the South-Western corridor in one of these two ways every year. ${ }^{27}$

An increasing effort was made regarding safety procedures and the rationalization of the interstate bureaucracy and controls, namely establishing mandatory and standardized technical requirements of vehicles and crew, regular technical inspections on the vehicles, and control of the

26 . The use of air transport by migrants was already expressive in the late 1960s, but it was to travel to the Americas and to the Portuguese Atlantic Islands. Except for the cases where the destination was Venezuela, the airplane substituted the ship to cross the Atlantic (See statistics in Boletim da Junta Nacional da Emigração). The travel costs from Lisbon to Paris by air were 5 times more expensive than by coach in 1985. At the time, there were almost 2 million migrants traveling (in both ways) by car, 300 thousand by coach, 160 thousand by rail and more than 400 thousand by air.

27. See SPAIN, Centre d'Etudes des Transports pour la Méditerranée Occidentale. 1988. Rapport Final des Reúnions Informelles sur l' Analyse des Flux de Trafic entre la France et la Peninsule Ibérique/Magreb. Barcelona, Centre d'Etudes des Transports pour la Méditerranée Occidentale, p. 60. 
drivers' professional education and behavior on the road. A common waybill and controls replaced the former list of passengers and measures were applied to suppress the double inspections and to reduce the long time spent crossing borders. These processes, which came into force, required daily collaborative work between different administrations, and divergent interests on each issue were often settled through negotiation. ${ }^{28}$ In the international forums, namely IRU (International Road Transport Union), there was a movement against 'excessive control' and 'bureaucratic' procedures that created long stops in the borders (control of the passengers' list, travel documents, vehicles inspections, the quantity of fuel, and taxes), and during travels, which was regarded as a 'crypto-protectionism' (Groenendijk 1983). The ASOR Treaty, signed in Dublin in 1982, reflected these concerns but was restricted to occasional services. $^{29}$

The previous experience and the business model were generalized in 1985 when Eurolines was created. The new company integrated and coordinated in a new pool and under the same brand the exploration of the regular international lines, which belonged to the previous coach companies already operating in the European South-Western corridor, aiming "to reinforce the collaboration between partners to harmonize the conditions of technical, commercial and legal exploration". ${ }^{30}$

28. For instance, in 1981 the French administration threatened to suspend the line Paris-Porto and all coach services that did not follow the AETR. A previous agreement between Internorte and the International Autocares that involved a crew of two drivers for 26-hour travels, was cancelled. (See IMTT archive, Lines Portugal-France, Official letter dated Februrary 27th, 1981, from the Service des Transports Interurbains de Voyagers. Direction Génerale des Transports Terrestres). Two years later, a joint commission settled the modus operandi of the new lines from Portugal to Germany.

29. The multilateral Agreement on the International Carriage of Passengers by Road by means of Occasional Coach and Bus Services (ASOR) entered into force in 1983 and followed the EEC regulations and the ECMT resolution 20. It concerned only occasional coach services. More recently, in 2003, the Interbus agreement was signed by the EC, Bosnia and Herzegovina, Bulgaria, Croatia, Moldova, Romania and Turkey.

30. Today, Eurolines announces itself as 'The European Grey Hound', with 24 companies that explore regular lines in Portugal, Spain, France, Italy, Turkey, Switzerland, Netherlands and United Kingdom joining the pool.

\section{Conclusion}

The historiography of the European migration following the II World War often underestimates the role of transport networks in the configuration of the migration flows and how they promoted and supported seasonal, temporary, and permanent work migration. To some extent it has been almost an 'invisible phenomenon' since historical (official) data series usually consider the traffic by transport modes, on one hand, and the number of foreign residents and tourists, on the other. Company reports usually give us data regarding the production of long-distance services while direct inquiries to users often lack accuracy. Given the high regulatory European migration framework, many of these movements tend to be 'invisible' and often 'irregular'.

Since the 1960s, the transnational bus services in the Southwest European corridor provided cheaper travel mainly for migrant workers. They connected rural and poor areas of the European periphery with the rich and industrialized regions. This also affected the migrants' countries of origin in various aspects: eventhough urbanization, foreign investment and tourism grew, regional asymmetries increased, with rural communities impoverishing and aging. The coach firms stimulated (if not triggered) this flux, being efficient in the use of the flexibility of the coach and the road infrastructure. The migrants' need for transportation became an important market for bus companies, and that was the cause for policies imposed by governments to control traffic and to protect the interests of the national transport groups. For that reason, they experienced a coordinated and shared administration that was part of a larger process of normalization in the European context. The internationalization of the nationalist and technical elite followed that trend of opening towards 'Europe' that changed the new generations.

In the beginning, the international coach lines contributed to the rural-urban population flows at European scale, deeply changing social and economic landscapes. They later evolved and became an infrastructure for more complex and diversified mobility patterns. Eastern migrants (Ukrainians, Moldavians, and Bulgarians) often 
arrived to Portugal by coach, and Brazilians and Africans traveled to Europe as tourists. Since the 1980s, the coaches used in regular services became more secure (better breaks and greater motor power), more reliable, and comfortable (with anatomic seats, soundproofing, air conditioning, toilets onboard). However, the most important improvement in the travel experience came from the highway infrastructures built in the Iberian Peninsula in the 1990s, combined with the elimination of border control and forced stops. The price of tickets and luggage are still the main strengths of these companies, and many youths use them for touring across Europe. Despite the decline of the emigration flows to the western European countries from the European Mediterranean basin, and the increasing use of air travel and individual transportation, the long-distance coach services maintained relevance in the 1990s. They adapted to the new scenario and the changing patterns of transnational mobility flow in Europe and clientele. They became an infrastructure for seasonal East-West work migrants that are competing with the previous flows from northern Africa, for transnational 'double residents' and 'tourists'. ${ }^{31}$ Thus, in 2003 there were 135 regular international passenger road lines mainly to France, Germany, and Spain.

\section{Acknowledgements}

This study was conducted at the Research Center in Political Science (UID/CPO/00758/2020), University of Évora, and was supported by the Portuguese Foundation for Science and Technology and the Portuguese Ministry of Education and Science through national funds.

The previous versions of this text were presented at the European Science Foundation SCH Exploratory Workshop: Eurobus at Helmond (The Netherlands) 11-13 June 2009 convened by Gijs Mom and John Walton and at the Eighth International Conference on the History of Transport,

31. See for instance Negre 2009. In the article entitled 'The nightmare of the bus Madrid-Bucareste' the journalist captured one of those flows, telling the story of the "Romanians living in Spain and returning to Bucharest on holiday [that] are being exploited by fraudulent bus companies. The lure of cheap fares seems too good to be true. Illegal operators often clog up the toilets with goods, bribing customs officers, and in some cases, leaving passengers in the middle of the journey on foot".
Traffic and Mobility (T2M), New Delhi, India December 2, 2010 and published in Zeitschrift fur Weltgeschichte, 12(2), 2011, pp.175-237 (translated by Ralph Roth). The research was partially financed by the Portuguese Science Foundation (FCT - FEDER/POCI 2010). The author is grateful to José Luís Covita, Gijs Mom and John Walton for their comments. 


\section{Referências}

[1] Babiano, José and Rodríguez Farré. 2002. "La emigracion española a Europa durante los años sessenta: Francia y Suiza como países de acogida". Historia Social, (42): 81-97.

[2] Bade, Klaus J. 2002. L'Europe en Mouvement: la migration de la fin du XVIIIe siècle à nos jours. Paris: Éditions du Seuil.

[3] Baganha, M. I. 2003. "From Closed to Open Doors: Portuguese Emigration under the Corporatist Regime". e-Journal of Portuguese History I, (1) 2003: 1-16.

[4] Braga, Miguel Sequeira et al. 1969. Anteprojecto de Regulamentação dos Transportes Internacionais Rodoviários. Lisboa: GEPMT.

[5] Castles, S. 1986. "The Guest-Worker in Western Europe An Obituary". International Migration Review, 20(4): 761778.

[6] CEMT. Conference Europeenne des Ministres des Transports. 1966. "Regulation $117 / 66 / \mathrm{CEE}$ approved by the Council at September, 28th 1965 regarding the introduction of common rules for the road passenger transport by coaches". Journal Officiel du Conseil, July 28th, 1966.

[7] CEMT. 1979. Rapport de la Quarente-Quatrième Table Ronde d'Economie des Transports, 59. Paris: CEMT.

[8] CEMT. Centre de Recherches Économiques. 1988. Rapport de la Soixante-Douzième Table Ronde d' 'Economie des Transports tenú à Paris les 26 et 27 mars 1987 sur le thême: Le Transport International par Autocar. Paris: CEMT.

[9] Groenendijk, P. 1983. «L'Avenir du Transport Routier: Compromis par les Obstacles aux Frontiers. Union Internationale des Transport Routiers», XIXe Congres de L'IRU, Venice.

[10] Lobato, Luís Guimarães. 2005. A Concepção da Rede Ferroviária no Sistema Global de Transportes: o Gabinete de Estudos e Planeamento de Transportes Terrestres. Lisboa: DGTTF; CP.

[11] Marques, J. C. 2009. "«E continuam a partir»: as migrações portuguesas contemporâneas". Ler História, (56): 2744.

[12] Mavropolos, M., and Jean Louis-Larronde. 2008. «J'aime tous dans ce metier». Autocar $\&$ Bus infos.

[13] Mendoza, Cristobal. 2009. Inmigracion laboral africana en la Peninsula Iberica. Mexico, D.F., Universidad Autónoma Metropolitana Unidad Iztapalapa.

[14] Messina, A. M. 2002. West European Immigration and Immigrant Policy in the New Century. Westport: CT.

[15] Moch, Leslie P. 2003. Moving Europeans: Migration in Western Europe since 1650. Bloomington \& Indianapolis: Indiana University Press.

[16] Negre, Javier G. 2009. "O pesadelo do autocarro MadridBucareste". El Mundo, Madrid, 21 August 2009. Available at http://www.presseurop.eu/pt/content/article/81931o-pesadelo-do-autocarro-madrid-bucareste (last access 8/02/2011).

[17] Pérez Dias, A. and G. Barrientos Alfageme, eds. 2005. Emigrantes Retornados e Inmigrantes: Extremadura ante el Siglo XXI. Badajoz: Diputación Provincial.

[18] Pereira, V. 2009. "Ineficiência, fragilização e duplicidade: o velho Estado Novo perante a emigração para França (19601968)". Ler História, (56): 45-68.

[19] Portugal. Instituto da Mobilidade e dos Transportes Terrestres (IMTT) Archive / Conselho Superior dos Transportes CSTT. 1952 - Proceeding 112. Book 4, f. 171.

[20] Portugal, Ministério dos Transportes e Comunicações (MTC). GEPT, 1967. Relatório de Actividades, 1961-1966. Lisboa.
[21] Portugal, MTC. 1969. Gabinete de Estudos e Planeamento: Repport 28/69. Lisbon, GEPT. Mimeographed.

[22] Portugal, MTC. GEP. 1987. Informação complementar ao Relatório 'Portugal: Contributos para o Estudo do Corredor Sudoeste da Europa'. Lisboa. (Copygraph).

[23] RN. Rodoviária Nacional. 1985. Relatórios e Contas de 1984. Lisboa.

[24] Salt, John and Hugh Clout eds. 1976. Migration in PostWar Europe: Geographical Essays. Oxford: University Press.

[25] Schipper, Frank. 2008. Driving Europe: Building Europe on Roads in the Twentieth Century. Amesterdam: Aksant.

[26] Tapia, S. 1996. "Échanges, transports et communications: circulation et champs migratoires turcs". REMI, 12(2): 4571.

[27] Triadafilopoulos, T. S. and Karen Schonwalder. 2007. "How the Federal Republic Became an Immigration Country: Norms, Politics and the Failure of West Germany's Guest Worker System". German Politics and Society, 24(3).

[28] Villanova, Roselyne. 2006/7. "Double Residence": A Space for Intergenerational Relations. Portuguese Immigrants in France in the Twentieth and Twenty-First Centuries. Portuguese Studies Review, 14(2): 241-261.

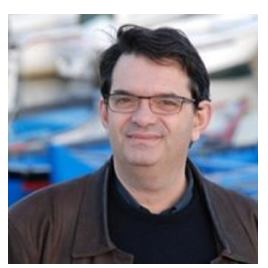

Paulo Guimarães is an Assistant Professor at the University of Évora and Integrated member of the Research Center in Political Science (CICP). Paulo Guimarães has a $\mathrm{PhD}$ in History from the University of Évora (Portugal), and he is a board member of the Doctoral Programme in Contemporary History at the same university. He is the author of "Elites and Industry in Alentejo (1890-1960): a study on economic behaviour of elite groups in regional context (Lisbon, 2005)"and of "Industry and Conflict in the Rural Milieu: The Miners of Alentejo (1858-1938)". 